had developed a duodenal ulcer, one a gastric ulcer, one a combined duodenal and gastric ulcer, and one was found to have radiological evidence of achalasia of the cardia. These patients were referred for surgical treatment, with excellent results in all except the patient with achalasia. Of the four remaining patients, further radiological investigation had shown renal disease in two, but with no evidence of gastrointestinal disease, and two were again found to have no abnormality.

When the radiological diagnosis for the 1964 barium-meal study was compared with the follow-up diagnosis six years later it changed in eight cases. Six, as indicated above, developed upper gastrointestinal lesions, and two were found to have renal disease. None of these patients experienced gastrointestinal haemorrhage or perforation during the period of follow-up. Six had died, but in none was the recorded cause of death attributable to a lesion in the upper gastrointestinal tract.

\section{Discussion}

An increasing number of patients with dyspepsia are referred for radiological investigations by their general practitioners because a peptic ulcer is suspected. In this series few (3.5\%) of those patients with a normal finding on barium-meal examination in 1964 were later found to have a peptic ulcer. Most showed appreciable symptomatic improvement, 65 (76\%) claiming to have little or no dyspepsia when questioned in 1970. Fifteen patients claimed there had been no change in their symptoms. The five patients shown by the questionnaire to have deteriorated symptomatically were reinvestigated, and in two a positive diagnosis was obtained.

Similar groups of patients studied over an extended period have shown a much higher incidence of peptic ulceration in follow-up. In a group of 174 hospital patients who were followed for 27 years, $40 \%$ were shown to have a peptic ulcer at subsequent investigations (Krag, 1965). Brummer and Hakkinen (1959) followed 102 patients over a six-year period and found that 12 had developed a peptic ulcer. Barfred (1959) followed 235 patients over a 10-year period, and $30 \%$ developed a peptic ulcer during this time.

The lower incidence of peptic ulcer in our study may be related to two factors. Firstly, all of the present patients were referred directly from general practitioners, whereas the reports referred to above all dealt with a hospital population. Secondly, a longer follow-up period would possibly have given a higher incidence of the subsequent development of peptic ulceration. We believe that this would be unlikely as $76 \%$ of the present patients were virtually symptomless six years later.

If we assume that " $x$-ray-negative dyspepsia" represents a separate disease entity then its prognosis is more favourable than for peptic ulcer, most patients showing appreciable improvement with time. If further investigations are reserved only for those patients who show a deterioration symptomatically then the burden of repeated reinvestigations both for the radiological services and the patients will be eased, so reducing unnecessary investigations.

We would like to thank Professor H. Campbell, of the department of medical statistics, for advice in the planning of this study, and also Mrs. R. Moss for secretarial help.

\section{References}

Barfred, A. (1959). Proceedings of the World Congress on Gastroenterology, p. 352. Baltimore, Williams and Wilkins.

Brummer, P., and Hakkinen, I. (1959). Acta Medica Scandinavica, 165, 329.

Krag, E. (1965). Acta Medica Scandinavica, 178, 713

Lipetz, S., Sklaroff, S. A., and Stein, L. (1955). British Medical fournal, 2, 172 .

\title{
Viral Infection and Renal Transplant Rejection
}

\author{
J. D. BRIGGS, MORAG C. TIMBURY, A. M. PATON, P. R. F. BELL
}

British Medical fournal, 1972, 4, 520-522

\section{Summary}

The occurrence of an outbreak of influenza in a renal transplant unit is described. Five patients had a proved episode of infection, confirmed by a rise in the complement fixation titre to influenza virus $A$, and this coincided in three of the patients with episodes of acute rejection. It seems likely that the virus infection was responsible for the rejection, possibly through a stimulating effect of the virus on the host's immune response.

\section{Introduction}

Rejection remains the most common and important complication of renal transplantation. In some cases factors which pre-

Renal Unit, Western Infirmary, Glasgow

J. D. BRIGGS, M.B., M.R.C.P., Consultant Physician

A. M. PATON, M.B., M.R.C.P., Medical Registrar

Institute of Virology, University of Glasgow

MORAG C. TIMBURY, M.D., M.R.C.PATH., Senior Lecturer

University Department of Surgery, Western Infirmary, Glasgow P. R. F. BELL, M.D., F.R.C.S., Consultant Surgeon cipitate the rejection can be defined, such as a reduction in dosage of immunosuppressive drugs. In most patients, however, rejection episodes occur without warning and in the absence of obvious precipitating factors. Rarely, an association has been noted between viral infection and rejection (Simmons et al., 1970; David et al. 1972). This paper describes the occurrence of a localized outbreak of influenza associated with acute rejection.

\section{Outbreak}

In the winter of 1971-2 there was an epidemic of influenza due to $\mathrm{Al} /$ Hong Kong/68 virus in the West of Scotland. In January and February 1972 a localized outbreak of influenza occurred in the renal transplant unit of the Western Infirmary, Glasgow, which affected five patients with renal transplants and one patient on regular haemodialysis. The main features of the outbreak in the patients with transplants are summarized in the Table. Details of the clinical history of each patient are given below.

Case 1.-A 20-year-old man with membranous glomerulonephritis received a cadaver kidney on 30 Ocober 1971. Tissue typing showed HL-A antigens 2, 10, and 12 in both the donor and recipient, with one unidentified antigen at the second sublocus. 
Clinical Details of the Patients with Renal Transplants

\begin{tabular}{|c|c|c|c|c|c|c|}
\hline \multirow[t]{2}{*}{$\begin{array}{l}\text { Case } \\
\text { No. }\end{array}$} & \multirow{2}{*}{$\begin{array}{l}\text { Sex and } \\
\text { Age in } \\
\text { Years }\end{array}$} & \multirow{2}{*}{$\begin{array}{c}\text { Date of } \\
\text { Transplant }\end{array}$} & \multirow{2}{*}{$\begin{array}{l}\text { Date of } \\
\text { Onset of } \\
\text { Influenza }\end{array}$} & \multirow[t]{2}{*}{ Clinical Course } & \multicolumn{2}{|c|}{$\begin{array}{l}\text { Titres of Comple- } \\
\text { ment Fixation } \\
\text { Antibody to } \\
\text { Influenza Virus A }\end{array}$} \\
\hline & & & & & $\begin{array}{l}\text { Before } \\
\text { Illness }\end{array}$ & $\begin{array}{l}\text { Conval- } \\
\text { escence }\end{array}$ \\
\hline 1 & M. 20 & $30 / 10 / 71$ & $28 / 1 / 72$ & $\begin{array}{l}\text { Signs of rejection on } \\
31 / 1 / 72 \text {. Unevent- } \\
\text { ful recovery from } \\
\text { influenza }\end{array}$ & $<8$ & 512 \\
\hline 2 & F. 21 & $4 / 1 / 72$ & 29/1/72 & $\begin{array}{l}\text { Signs of rejection on } \\
30 / 1 / 72 \text {. Influenza } \\
\text { complicated by } \\
\text { pneumonia }\end{array}$ & $<8$ & 512 \\
\hline 3 & F. 19 & $18 / 9 / 71$ & $31 / 1 / 72$ & $\begin{array}{l}\text { Signs of rejection on } \\
2 / 2 / 72 \text {. Influenza } \\
\text { complicated by } \\
\text { pneumonia }\end{array}$ & $<8$ & 128 \\
\hline 4 & F. 42 & $8 / 10 / 71$ & $25 / 1 / 72$ & $\begin{array}{l}\text { No rejection. Un- } \\
\text { eventful recovery } \\
\text { from influenza }\end{array}$ & $<8$ & 64 \\
\hline 5 & M. 41 & $27 / 8 / 71$ & $14 / 1 / 72$ & $\begin{array}{l}\text { No rejection. Un- } \\
\text { eventful recovery } \\
\text { from influenza }\end{array}$ & $<8$ & 256 \\
\hline
\end{tabular}

The kidney began to function after two weeks, and during the next four weeks the serum creatinine stabilized at a mean value of $1.2 \mathrm{mg} / 100 \mathrm{ml}$. On 28 January 1972 he developed coryza with a sore throat and cough. On 3 February he became pyrexial with shivering and headache, and these symptoms settled over the nex five days. A deterioration in renal function was first noted on 31 January with a rise in serum creatinine to $2 \cdot 2 \mathrm{mg} / 100 \mathrm{ml}$. By 6 February the level had reached a peak of $3.5 \mathrm{mg} / 100 \mathrm{ml}$, and fell steadily thereafter. Other features suggestive of acute rejection were an increase in bodyweight of $2.9 \mathrm{~kg}$ and a rise of blood urea from 60 to $130 \mathrm{mg} / 100 \mathrm{ml}$ between 31 January and 6 February. Four 1-g doses of intravenous prednisolone were given during this seven-day period. The oral immunosuppressive regimen, consisting of prednisolone $25 \mathrm{mg} /$ day and azathioprine 25 to $50 \mathrm{mg} /$ day was not altered. His renal function did not return to prerejection levels and four months later the mean serum creatinine was $2.2 \mathrm{mg}$ / $100 \mathrm{ml}$ although renal function was stable and his general condition excellent. On 14 February, 17 days after the initial onset of the influenza-like symptoms, complement fixation tests showed antibody to influenza virus $A$ at a titre of 512. This contrasted with a titre of less than 8 in a blood sample obtained two months earlier.

Case 2.-A 21-year-old girl with chronic glomerulonephritis received a cadaver kidney on 4 January 1972. Both HL-A antigens at the second sublocus were identical while there were two mismatches at the first sublocus. The diuretic phase began 10 days later, and the serum creatinine had fallen to $2.2 \mathrm{mg} / 100 \mathrm{ml}$ by 27 January. On 29 January she developed coryza with a productive cough, shivering, and pyrexia. By 3 February her temperature had risen to $103^{\circ} \mathrm{F}\left(39.4^{\circ} \mathrm{C}\right)$ and signs of pneumonia had developed. This was slow to resolve but had begun to improve by 9 February. On 30 January renal function began to deteriorate and the serum creatinine rose from $3.0 \mathrm{mg} / 100 \mathrm{ml}$ on that day to $4.0 \mathrm{mg} / 100 \mathrm{ml}$ on 9 February, thereafter falling to $2.1 \mathrm{mg}$ eight days later. Other features suggestive of acute rejection between 30 January and 9 February were a rise in serum urea from 106 to $146 \mathrm{mg} / 100 \mathrm{ml}$ and a fall in creatinine clearance from 28 to $17 \mathrm{ml} / \mathrm{min}$. Three months later the mean serum creatinine was $1.4 \mathrm{mg} / 100 \mathrm{ml}$. The rejection episode was treated with a total of three doses of intravenous prednisolone, each of one gramme. The oral prednisolone dose was reduced from 35 to $20 \mathrm{mg} /$ day on 3 February because of the pneumonia. Leucopenia developed on 30 January despite previously small daily doses of azathioprine, on average $25 \mathrm{mg}$. No azathioprine was therefore given between 31 January and 8 February. Eighteen days after the onset of the influenzal symptoms complement fixation tests showed antibody to influenza virus $A$ at a titre of 512 . The titre in a blood sample taken two months earlier was less than 8 .

Case 3.-A 19-year-old girl with chronic pyelonephritis received a cadaver kidney on 18 September 1971. There was identity of HL-A antigens between the donor and recipient at the first sublocus with two mismatches at the second sublocus. The diuretic phase started two weeks later with a steady improvement in renal function. On 24 January 1972 she developed an acute rejection, with a rise in serum creatinine from $1.7 \mathrm{mg}$ to a peak of $3.4 \mathrm{mg} / 100 \mathrm{ml}$ five days later. Thereafter it began to fall, but on 31 January a pyrexial illness developed with a productive cough and dyspnoea and two days later the serum creatinine began to rise again to reach a peak of $4.2 \mathrm{mg} / 100 \mathrm{ml}$ on 4 February. Clinical and radiological signs of pneumonia were present at this stage. By 6 February the pyrexial illness had begun to resolve, the body weight had fallen by $3 \mathrm{~kg}$ from its peak on 4 February, and the serum creatinine had begun to fall, reaching a value of $2.6 \mathrm{mg} /$ $100 \mathrm{ml}$ by 15 February. These features suggested acute rejection occurring in association with the pyrexial illness. The patient tolerated only small doses of azathioprine, and from the end of February 1972 this led to a progressive deterioration in renal function. The kidney was removed at the end of March and regular haemodialysis reinstituted. A total of seven $1-\mathrm{g}$ intravenous doses of prednisolone were used to treat the rejection episodes between 24 January and 4 February. Sixteen days after the onset of the pyrexial illness the titre of complement fixing antibody to influenza virus A was 128 , compared to a titre of less than 8 in a blood sample obtained two months earlier.

Case 4.-A 42-year-old woman developed influenzal symptoms on 25 January 1972, four months after a cadaver transplant. Her serum creatinine at this time was in the range 1.5 to $2.0 \mathrm{mg} / 100 \mathrm{ml}$, and the daily prednisolone dosage was $30 \mathrm{mg}$. No evidence of rejection developed. Twenty-one days after the onset of influenzal symptoms the titre of antibody to influenza virus $A$ by complement fixation test was 64 , compared to a titre of less than 8 in a blood sample obtained two months earlier.

Case 5.-A 41-year-old man received a cadaver kidney on 27 August 1971. On 14 January 1972 he developed shivering, pyrexia, and a cough. Influenza was confirmed by an antibody titre of 256 in complement fixation tests with influenza virus $A$ in a blood sample obtained 21 days later. The titre in the sample obtained before influenzal symptoms was less than 8 . No evidence of rejection appeared in association with the influenza.

\section{Discussion}

During a two-week period an outbreak of influenza occurred which involved five transplanted patients. The clinical features were typical, consisting of coryza, shivering, cough, and pyrexia. In two of the patients (Cases 2 and 3) the illness was complicated by pneumonia. In all five patients the diagnosis of influenza was confirmed serologically by the finding of a significant rise in the complement fixation titres to influenza virus $A$ when compared to the titres in blood samples obtained before the illness. Tests for antibody to other respiratory viruses were negative. In three of the five patients there was an associated temporary decline in renal function, as indicated by the serum creatinine and creatinine clearance values with, in addition, fluid retention. Also, in one of these three patients (Case 1) there was inhibition of leucocyte migration, using donor liver tissue as the antigen, at the onset of the deterioration in renal function. Serial tests in this patient up to this time had shown absence of inhibition. The leucocyte migration test has been shown to be of value in the prediction of rejection (Smith et al., 1969; Galamaud et al., 1972) and studies in our unit have confirmed this (R. F. M. Wood and A. R. Rafferty, unpublished observations, 1972). Leucocyte migration tests were not carried out in Cases 2 and 3.

There are several possible explanations for the temporary deterioration in renal function which occurred in the three patients. Infection with influenza virus A might have caused renal damage by direct infection of the kidney (Kaji et al., 1959 ) or by the deposition within the kidney of immune complexes of virus and antiviral antibody (Oldstone and Dixon, 1967). The clinical and biochemical features, however, rapid response in each case to intravenous prednisolone (Bell et al., 1971), and the inhibition of leucocyte migration in the patient in whom this test was performed provide good evidence for the diagnosis of rejection.

The interval between the onset of influenzal symptoms and the first signs of rejection in these three patients was 1,2 , and 3 days respectively. There were no clear-cut differences between the three who rejected and the two who did not, other 
than the fact that in two of the three who rejected (Cases 2 and 3) the influenza pursued a severe course with the development of pneumonia. The more severe course may in turn have been related to the fact that they were leucopenic at the time. Because of this they were receiving low doses of azathioprine, but in other respects the immunosuppressive regimen of the five patients was similar.

It is possible that the attacks of influenza and the onset of rejection in three of the transplanted patients were unconnected. The fact that the episodes of rejection took place within a five-day period during an outbreak of influenza, however, suggests that the rejection was precipitated by the virus infection. A similar association of rejection and virus infection has been described in three patients by David and his coworkers (1972), and infection in one was due to influenza virus A.

An explanation is required for the association between the influenza infection and rejection. Infection with the virus may have caused a general stimulation of the immune response of the patients. There is some evidence that influenza can produce stimulation of cell-mediated immunity. Thus spontaneous transformation has been observed in lymphocytes cultured from the peripheral blood of patients one to four weeks after infection with influenza virus A (Parker and Lukes, 1971; Field and Caspary, 1972). No studies of this sort were carried out on the present patients but it is of some interest that, despite immunosuppressive therapy, they all developed high levels of antibody to influenza virus. It may be that the episodes of rejection were due to a generalized stimulation of the immune mechanism, including cell-mediated immunity, after virus infection.

The apparent onset of rejection as a result of influenza raises the question of the advisability of vaccinating patients with transplants. Current influenza vaccines contain inactivated virus so that there is no risk of virus multiplication in the body.
However, the postulated stimulation of the immune response by influenza virus infection might also be brought about by inocculation of influenza vaccine, and one of the patients described by David and his co-workers (1972) in fact had a rejection episode one month after being vaccinated against influenza. Present influenza vaccines contain purified virus particles but research is going on into the development of a vaccine containing purified haemagglutinin derived from the surface of the virus particles. The haemagglutinin is the main antigen involved in immunity to reinfection and it may be that it could confer protection in the absence of a general stimulatory effect on immune mechanisms. It would, however seem wise to delay a decision on vaccinating patients with transplants against influenza until more is known of effects of different types of vaccines on the immune response.

We wish to thank Miss Elspeth Monteith for valuable technical help, and Dr. C. M. Bradstreet, of the Standards Laboratory, Colindale, London, for supplying complement fixation reagents.

Requests for reprints should be addressed to: Dr. J. D. Briggs, Renal Unit, Western Infirmary, Glasgow G11 6NT.

\section{Refirences}

Bell, P. R. F., et al. (1971). Lancet, 1, 876.

David, D. S., et al. (1972). Annals of Surgery, 175, 257.

Field, E. J., and Caspary, E. A. (1972). Lancet, 1, 963.

Galamaud, P., Crevon, M. C., Dormont, J., Mahieu, P., and Weydert, A. (1972). Transplantation, 13, 48.

Kaji, M., Oleasohn, R., Jordan, W. S., and Dingle, J. H. (1959). Proceedings of the Society of Experimental Biology and Medicine, 100, 272

Oldstone, M. B. A., and Dixon, F. J. (1967). Science, 158, 1193.

arker, J. W., and Lukes, R. J. (1971). In Proceedings of the 4th Annual Leucocyte Culture Conference, ed. O. Ross McIntyre, p. 281. New York, Appleton.

Simmons, R. L., Weil, R., Tallent, M. B., Kjellstrand, C. M., and Najarian, J. S. (1970). Transplantation Proceedings, 2, 419.

Smith, M. G. M., et al. (1969). British Medical fournal, 4, 275.

\title{
Specific IgM Antibody in Serum of Patients with Herpes Zoster Infections
}

\author{
CONSTANCE A. C. ROSS, ROSALINDA McDAID
}

British Medical fournal, 1972, 4, 522-523

\section{Summary}

Specific IgM varicella-zoster antibody was detected in "convalescent" sera from 20 out of 40 patients $(50 \%)$ with herpes zoster infections. Since these were not primary infections with varicella-zoster virus, it seems that detection of IgM antibody specific for a particular virus may not differentiate a primary infection from secondary infections with that virus.

\section{Introduction}

Several studies have shown that after primary immunization with many protein antigens an initial transitory IgM serum antibody response is obtained, whereas after secondary immunization an IgM response is usually difficult to detect

Regional Virus Laboratory, Ruchill Hospital, Glasgow

CONSTANCE A. C. ROSS, M.D., M.R.C.PATH., Consultant Virologist ROSALINDA MCDAID, Student Technician
(Pike, 1967). In several human viral infections it has also been shown that specific IgM antibody may be detected during the first few weeks of a primary infection (Schluederberg, 1965; Vesikari and Vaheri, 1968; Haire and Hadden, 1972). There have, however, been few opportunities to determine if IgM specific antibody can be detected during subsequent infections with a particular virus.

Epidemiological and clinical evidence indicate that herpes zoster is a secondary infection with varicella-zoster probably due to reactivation of virus which has remained latent for many years in the sensory ganglia after the primary infecton chickenpox (Hope-Simpson, 1965). The purpose of the present study was to determine if specific IgM antibodies could be detected by indirect immunofluorescence in sera of patients with herpes zoster infections.

\section{Materials and Methods}

Paired sera for the indirect immunofluorescence test were collected by general practitioners from 40 patients aged from 33 to 80 years with clinical herpes zoster, the first specimen being taken generally during the first few days of the illness 